\title{
Preliminary Evidence of Nocturnal Transpiration and Stomatal Conductance in Potato and their Interaction with Drought and Yield
}

\author{
David A. Ramírez ${ }^{1,2,3}$ (D) - Wendy Yactayo ${ }^{1}$ • José L. Rolando ${ }^{1,4} \cdot{\text { Roberto } \text { Quiroz }^{1}}^{1}$
}

Published online: 28 November 2017

(C) The Author(s) 2018

\begin{abstract}
In spite of the growing evidence showing the occurrence of nocturnal water exchange measured by stomatal conductance ( $\mathrm{SC}_{\text {night }}$, related to stomatal openness) and transpiration $\left(\mathrm{TR}_{\text {night }}\right.$, related to water losses) in different crops, how those processes are affected by soil water availability is still unknown. A preliminary study was conducted to test the occurrence of $\mathrm{TR}_{\text {night }}$ and $\mathrm{SC}_{\text {night }}$ (assessed in two moments) in two potato cultivars (UNICA and Sarnav), subjected to a long-term water restriction. The overall $\mathrm{TR}_{\text {night }}$ average were $9.0 \pm 0.6$ and $5.4 \pm 2.6 \%$ for total daily transpiration under well-watered and water restricted conditions, respectively. Cultivar differences in early night and predawn $\mathrm{SC}_{\text {night }}$ and $\mathrm{TR}_{\text {night }}$ were more evident under non-restricted water conditions. Tuber yield was linearly correlated with $\mathrm{TR}_{\text {night }}$ and predawn and early-night $\mathrm{SC}_{\text {night }}$. These preliminary findings emphasize the need for future research to corroborate the detection of $\mathrm{TR}_{\text {night }}$ and $\mathrm{SC}_{\text {night }}$ under water restrictions in potato, addressing the functional implications of these traits and the usefulness of $\mathrm{SC}_{\text {night }}$ for screening large sets of genotypes for potato breeding.
\end{abstract}

The original version of this article was revised due to a retrospective Open Access order.

David A. Ramírez

d.ramirez@cgiar.org

International Potato Center (CIP), Apartado 1558, Lima 12, Peru

2 Water Resources Doctoral Program, Universidad Nacional Agraria La Molina, Av. La Molina s/n, Lima, Peru

3 Gansu Key Laboratories of Arid and Crop Science, Crop Genetic and Germplasm Enhancement, Agronomy College, Gansu Agricultural University, Lanzhou 730070, China

4 North Florida Research and Education Center, University of Florida, Marianna, FL 32446, USA
Resumen Si bien existe creciente evidencia sobre la ocurrencia de intercambio de agua nocturna medida por la conductancia estomatal $\left(\mathrm{SC}_{\text {noche }}\right.$, relacionada con la abertura del estoma) y transpiración $\left(\mathrm{TR}_{\text {noche }}\right.$, relacionada a la pérdida de agua) en diferentes cultivos, aun se desconoce como estos procesos son afectados por la disponibilidad de agua en el suelo. Un estudio preliminar para probar la ocurrencia de $\mathrm{TR}_{\text {noche }}$ y $\mathrm{SC}_{\text {noche }}$ (evaluado en dos momentos) fue llevado a cabo en dos variedades de papa (UNICA y Sarnav), sujetas a restricción hídrica prolongada. El promedio de $\mathrm{TR}_{\text {noche }}$ correspondió entre $9.0 \pm 0.6$ y de $5.4 \pm 2.6 \%$ del valor de la transpiración diaria total bajo condiciones de buen suministro de agua y de restricción hídrica, respectivamente. Las diferencias entre variedades en $\mathrm{SC}_{\text {noche }} \mathrm{y} \mathrm{T}_{\text {noche }}$ medidas temprano en la noche y previo al amanecer fueron más evidentes bajo condiciones sin restricción de agua. El rendimiento de tubérculo estuvo correlacionado linealmente con $\mathrm{TR}_{\text {noche }}$ y $\mathrm{SC}_{\text {noche }}$ medida temprano en la noche y preamanecer. Estos hallazgos preliminares enfatizan la necesidad de investigación futura para corroborar la detección de $\mathrm{TR}_{\text {noche }} \mathrm{y} \mathrm{SC}_{\text {noche }}$ bajo restricciones de agua en papa, analizándose las implicaciones funcionales de estos caracteres y la utilidad de $\mathrm{SC}_{\text {noche }}$ para la evaluación de grandes grupos de genotipos para el mejoramiento de papa.

Keywords Nocturnal transpiration $\cdot$ Night-time conductance $\cdot$ Solanum tuberosum $\cdot$ Water restriction

\section{Introduction}

Potato is the third most important edible crop in the world (FAO 2016), and the assurance of its water requirements should be determined in order to manage its high sensitivity to water deficit (Ahmadi et al. 2010). Inappropriately adjusted 
irrigation and random precipitation events expose this crop to water restriction conditions affecting yield (Monneveux et al. 2013). Different models predicting potato water demand for irrigation scheduling have been reported (Raymundo et al. 2014). Most of them are based on the Penman-Monteith equation, which assumes the occurrence of stomatal closure with the concomitant absence of transpiration during dark conditions (Monteith and Unsworth 2001). It is worth highlighting that predawn water potential has been taken as a potato water status descriptor assuming that during the night, plant and soil are in equilibrium due to transpiration preclusion caused by stomatal closure (e.g. Tourneux et al. 2003; Rolando et al. 2015). Notwithstanding, the growing evidence that crops transpire important water amounts at night (Blom-Zandstra et al. 1995; Caird et al. 2007a; Schoppach et al. 2014; Resco de Dios et al. 2015) contradicts the water use modeling assumption of absent nocturnal water losses via transpiration $\left(\mathrm{TR}_{\text {night }}\right)$. One important issue that has not been fully addressed is the likely occurrence of $\mathrm{TR}_{\text {night }}$ during water restriction periods. Since water conservation through stomatal closure - even during low intensity droughts - has been documented in potato (Ramírez et al. 2016) and considering that $\mathrm{TR}_{\text {night }}$ occurrence requires an additional energy investment for plants (Caird et al. 2007b), we hypothesized a significant reduction of this process during water restriction. This preliminary work reports $\mathrm{TR}_{\text {night }}$ and nocturnal water stomatal conductance $\left(\mathrm{SC}_{\text {night }}\right.$, positive related to stomatal openness) at maximum physiological performance growing period in two advanced drought resistant potato clones (UNICA and Sarnav) under water restriction and full irrigation. Our goal was to ascertain soil water availability effects on $\mathrm{SC}_{\text {night }}$ and $\mathrm{TR}_{\text {night }}$ and their relationship with tuber yield.

\section{Materials and Methods}

\section{Study Site, Plant Material and Management}

The experiment was carried out between June 5 th and September 9th 2014 (usual growing season in the region) at the International Potato Center (CIP) - La Molina experimental station in Lima-Peru (12.1 ${ }^{\circ} \mathrm{S}, 77.0^{\circ} \mathrm{W}, 244$ m.a.s.1.). Forty-eight tubers of UNICA (CIP code $N^{\circ} 392,797.22$ ) and Sarnav (CIP code $\mathrm{N}^{\circ} 397,077.16$ ) cultivars were sown in pots (5.8 L) filled with a PRO-MIX and sand substratum (2:1 ratio). PRO-MIX (Premier Tech Horticulture, Canada) is a humic soil substrate with a high water retention capacity (a field capacity of $30.8 \%$ of volumetric water content). The pots were located in a glasshouse with automatized control of temperature (see specifications in Rolando et al. 2015). Each pot was fertilized with $4.0 \mathrm{~g}, 1.6 \mathrm{ml}$ and $8.45 \mathrm{~g}$ of $\mathrm{NH}_{4} \cdot \mathrm{NO}_{3}(31 \% \mathrm{~N})$, $\mathrm{H}_{3} \mathrm{PO}_{4}\left(53 \% \mathrm{P}_{2} \mathrm{O}_{5}\right)$ and $\mathrm{KNO}_{3}\left(13 \% \mathrm{~N}\right.$ and $\left.46 \% \mathrm{~K}_{2} \mathrm{O}\right)$ respectively, distributed in 14 weekly applications. The local average daily temperature, relative humidity, solar radiation and vapor pressure deficit during the growing period were $15.28 \pm 0.09{ }^{\circ} \mathrm{C}, 89.83 \pm 0.36 \%, 8.03 \pm 0.40 \mathrm{MJ} \mathrm{m}^{2}$ day $^{-1}$ and $0.18 \pm 0.0072 \mathrm{kPa}$ respectively (HOBO U12 Outdoor/ Industrial Data Logger, Onset Computer Corporation, Bourne, MA, USA).

Long-term water restriction was induced after tuber initiation; i.e. when stolon tips were twice the diameter of subtending stolon, determined through sequential harvesting of eight plants per cultivar. Tuber initiation occurred at 39 and 34 days after planting for UNICA and Sarnav. Following a completely randomized design in a glasshouse, 16 plants per cultivar were randomly assigned to control (field capacity) and water restriction treatments, 8 plants per treatment. Plants submitted to water restriction were irrigated to $50 \%$ of field capacity, guided by gravimetric assessment of all the plants, as described by Rolando et al. (2015). The irrigation was carried out twice per week up to harvest.

\section{Physiological Measurements}

Physiological measurements were taken at 70 days after planting (DAP, i.e. 31 and 36 days after tuber initiation onset for UNICA and Sarnav respectively), time at which both cultivars reached their maximum canopy cover, tuber bulking rate and photosynthetic performance (Rolando et al. 2015). Nocturnal water stomatal conductance $\left(\mathrm{SC}_{\text {night }}\right)$ was assessed both at early-night (8:30 pm - 10:30 pm) as well as at predawn (2:30 am - 4:30 am) using a portable photosynthesis system (LI6400 TX model, LI-COR, Lincoln, NE, USA). In both periods the following parameters were fixed in the cuvette: boundary layer $=9.3 \mathrm{~mol} \mathrm{~m}^{-2} \mathrm{~s}^{-1}, \mathrm{CO}_{2}$ concentration $=400 \mathrm{ppm}$ and air temperature $=20^{\circ} \mathrm{C}$. Nocturnal transpiration $\left(\mathrm{TR}_{\text {night }}\right)$ was assessed gravimetrically in tandem with $\mathrm{SC}_{\text {night }}$, by covering the soil surface of the pots with a transparent plastic to preclude evaporation losses. $\mathrm{TR}_{\text {night }}$ was estimated as the pot weight difference from 6:30 pm to 6:00 am of the following day. Total day transpiration was assessed through the weight difference in a period of $24 \mathrm{~h}$. Tuber fresh biomass was measured 96 DAP, weighting all the tubers per plant.

\section{Statistical Analysis}

The effect of cultivars and watering treatments on $\mathrm{SC}_{\text {night }}$ and transpirations (nocturnal and daily) were assessed through an ANOVA, followed by a Fischer's Least Significant Difference (LSD) test. A paired two sample t-Test was used to compare periods of $\mathrm{SC}_{\text {night }}$ (early-night and predawn). Linear regression analyses were performed - as described by Resco de Dios et al. (2016) - to explain tuber fresh biomass with $\mathrm{SC}_{\text {night }}$ and $\mathrm{TR}_{\text {night }}$ taken at maximum physiological performance. All the statistical analyses were run using SAS 191 v.8.02 software (SAS Institute, Cary, NC, USA). 
Table 1 Results of two-way Analyses of Variance testing the effect of cultivars, water treatments and their interaction in nocturnal transpiration $\left(\mathrm{TR}_{\text {night }}\right)$, total daily transpiration $\left(\mathrm{TR}_{\text {daily }}\right)$, early-night and predawn nocturnal stomatal conductance $\left(\mathrm{SC}_{\text {night }}\right) .{ }^{*} P<0.05$, $* * P<0.01$, n.s. $P>0.05$

\begin{tabular}{llll}
\hline & \multicolumn{2}{l}{ F-value } & \\
\cline { 2 - 4 } & Cultivars & Water treatments & Interaction \\
\hline $\mathrm{TR}_{\text {night }}$ & $23.1^{* *}$ & $124.0^{* *}$ & $18.6^{*}$ \\
$\mathrm{TR}_{\text {daily }}$ & $7.4^{* *}$ & $140.0^{* *}$ & $4.1 \mathrm{n} . \mathrm{s}$. \\
Early-night $\mathrm{SC}_{\text {night }}$ & $4.8^{*}$ & $23.3^{*}$ & $1.5 \mathrm{n} . \mathrm{s}$. \\
Predawn $\mathrm{SC}_{\text {night }}$ & $13.8^{*}$ & $35.4^{*}$ & $7.5^{*}$ \\
\hline
\end{tabular}

\section{Results and Discussion}

\section{Nocturnal Stomatal Conductance and Transpiration}

Significant differences for $\mathrm{SC}_{\text {night }}$ at early-night and predawn period were observed between cultivars and water treatments,
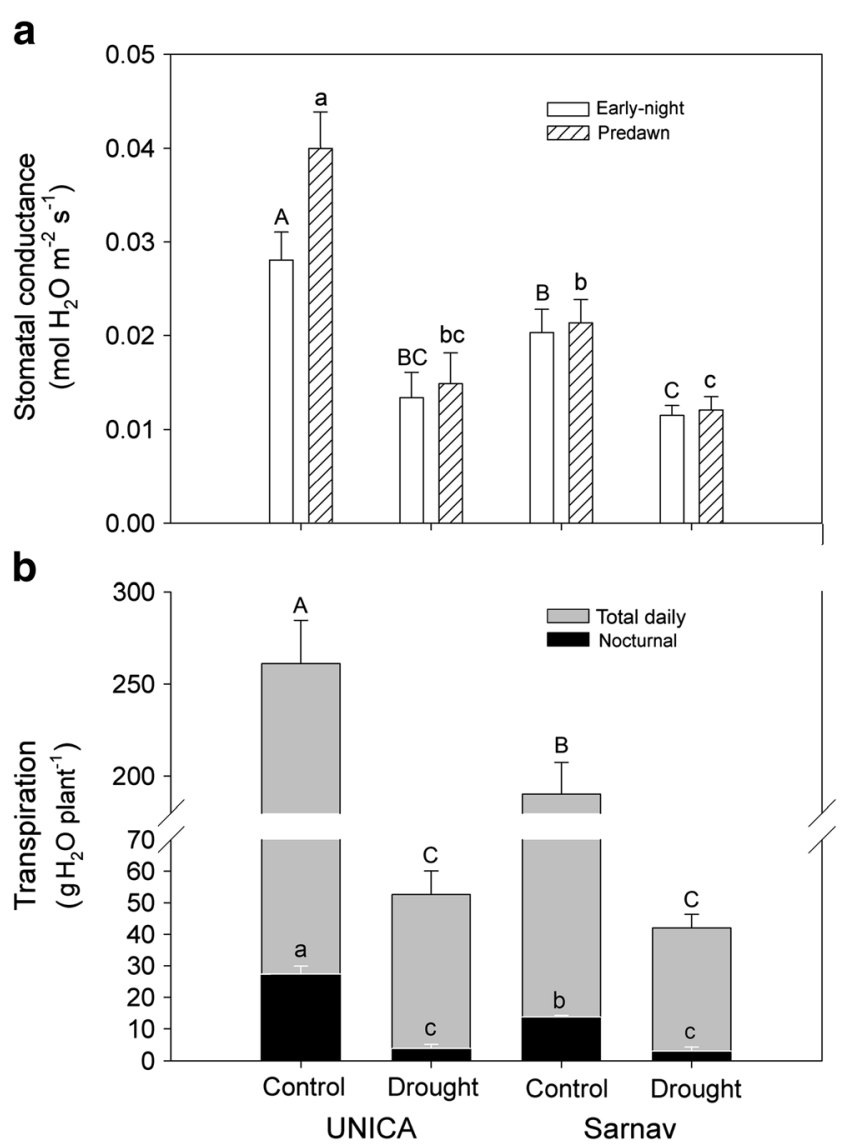

Fig. 1 Average nocturnal stomatal conductance (a) and transpiration (b) under two water status in UNICA and Sarnav cultivars. Different capital letters in A and B mean significant differences among early-night stomatal conductance and total daily transpiration using LSD test. Different lower case letters in A and B mean significant differences among predawn stomatal conductance and nocturnal transpiration using LSD test respectively (Table 1 ). The interaction cultivars $\times$ water treatment was significantly different only at predawn period (Table 1). The paired two sample t-Test between early-night and predawn $\mathrm{SC}_{\text {night }}$ showed differences (at $\mathrm{P}<0.01$ ) only for UNICA under well-watered conditions (Fig. 1a). The highest
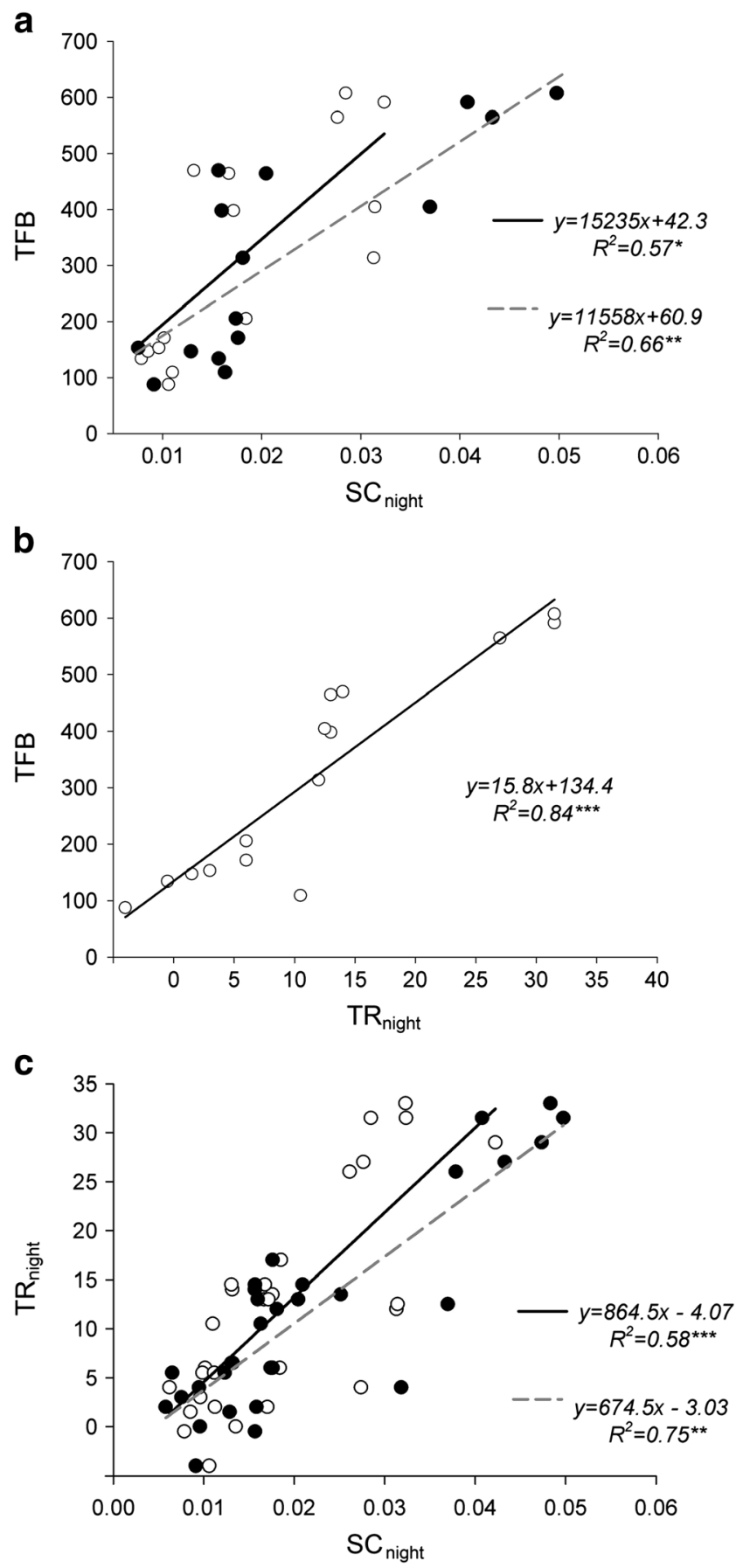

Fig. 2 Linear functions fitted to explain tuber fresh biomass (TFB, g plant $\left.{ }^{-1}\right)$ and nocturnal transpiration $\left(\mathrm{TR}_{\text {nigth }}, \mathrm{g} \mathrm{H}_{2} \mathrm{O}\right.$ plant $^{-1}$ night $\left.^{-1}\right)$ variability through their relationship with nocturnal stomatal conductance $\left(\mathrm{SC}_{\text {night }}, \mathrm{mol} \mathrm{H}_{2} \mathrm{O} \mathrm{m}^{-2} \mathrm{~s}^{-1}\right.$ ) measured at early-night (open circles, black continuous line) and predawn (black circles, grey dashed line). $* P<0.01, * * P<0.001, * * * P<0.0001$ 
value of $\mathrm{SC}_{\text {night }}$ was detected at predawn under well-watered conditions in UNICA (see Fig. 1a). This value was in the range of predawn $\mathrm{SC}_{\text {night }}$ values reported for other Solanaceae species $\left(0.04-0.10 \mathrm{~mol} \mathrm{H}_{2} \mathrm{O} \mathrm{m}^{-2} \mathrm{~s}^{-1}\right.$; Caird et al. 2007a). It has been suggested that predawn $\mathrm{SC}_{\text {night }}$ is related to the degree of circadian control which determines plant readiness to anticipate the beginning of the day (Resco de Dios et al. 2016) with important influences in the control of $\mathrm{TR}_{\text {night }}$ (Resco de Dios et al. 2015). This readiness is, in turn, associated to the circadian resonance, which reflects the degree of connection of endogenous rhythms with environmental light-dark cycles (Dodd et al. 2005) determining the success of a specie by fitness advantage (McClung 2006).

Significant differences for $\mathrm{TR}_{\text {night }}$ and total daily transpiration were observed between cultivars and watering treatments, respectively (Table 1). The interaction cultivars $\times$ watering treatment was significantly different only in $\mathrm{TR}_{\text {night }}$ (Table 1 ). The average percentage of $\mathrm{TR}_{\text {night }}$ in relation to the total daily transpiration under non-restricted and water restricted conditions were: $10.6 \pm 0.5 \%$ and $4.2 \pm 4.7 \%$ for UNICA, and $7.7 \pm 0.7 \%$ and $6.4 \pm 1.5 \%$ for Sarnav, respectively (Fig. 1b). The observed values under non-restricted watering conditions were in the range of other Solenaceae crops (7.7-10.6\%; Caird et al. 2007a), but they were lower than the values reported for roses (35-55\%, Blom-Zandstra et al. 1995) and wheat genotypes (13.8-54.9\%, Schoppach et al. 2014) assessed under no water restriction. Our night-time vapor pressure deficit $\left(\mathrm{VPD}_{\text {night }}\right)$ during the $\mathrm{TR}_{\text {night }}$ assessment ranged from 0.10 to $0.23 \mathrm{kPa}$ which are low values, typical of the Peruvian Coast characterized by high atmospheric humidity. Because $\mathrm{VPD}_{\text {night }}$ is considered one of the main drivers of $\mathrm{TR}_{\text {night }}$ (Schoppach et al. 2014), we hypothesize that potato could potentially show higher $\mathrm{TR}_{\text {night }}$ in regions with higher $\mathrm{VPD}_{\text {night }}$ and genotypes with larger predawn $\mathrm{SC}_{\text {night }}$ values (see Fig. 1a). Given the occurrence of $\mathrm{TR}_{\text {night }}$ under water restriction (an average of $5.4 \pm 2.6 \%$ of the total daily transpiration, see Fig. 1b) and the additional energy investment it entails (Caird et al. 2007b), $T_{\text {night }}$ in potato could be functionally involved in other physiological processes. In other species, $\mathrm{TR}_{\text {night }}$ has been linked to mass flow enhancing soil nutrients uptake (Caird et al. 2007b; Matimati et al. 2014), carbohydrates exportation associated to dark respiration (Marks and Lechowicz 2007), and other processes (Schoppach et al. 2014) that require further research in potato.

\section{Relationship between Tuber Yield and Physiological Variables}

The variables that better explained fresh tuber biomass were $\mathrm{TR}_{\text {night }}$ and predawn $\mathrm{SC}_{\text {night }}$ (Fig. 2a,b), whereas $\mathrm{TR}_{\text {night }}$ was mostly related to predawn $\mathrm{SC}_{\text {night }}$ (Fig. 2c). Our results agree with recent findings (Resco de Dios et al. 2016) which support the novel hypothesis that circadian resonance play a crucial role in maximum assimilation, biomass accumulation and fitness. The high $\mathrm{C}$ allocation to tubers in the potato crop (harvest index ranged between 0.67-0.87, Condori et al. 2010), and the capacity to anticipate daylight leading to a high predawn $\mathrm{SC}_{\text {night }}$, might hint a fast-adapting to starting and quenching photosynthesis process in improved genotypes.

\section{Conclusion}

The high $\mathrm{TR}_{\text {night }}$ in potato, even in conditions of low $\mathrm{VPD}_{\text {night }}$ and soil water deficit, is not consistent with the occurrence of stomatal closure at night, an assumption that should be reanalyzed for water balance modeling and water status estimations in this crop. The preliminary results reported in this study emphasize the necessity to understand the physiological processes in which $\mathrm{TR}_{\text {night }}$ is involved and why potato plants transpire at night even under water restriction conditions. Future studies must assess $\mathrm{SC}_{\text {night }}$ and $\mathrm{TR}_{\text {night }}$ throughout the growing season (not restricted to the season of maximum physiological performance), with more genotypes, different water restriction levels and environments. The hypothesis that circadian resonance, through daylight anticipation, might be involved in regulating tuber biomass accumulation in this crop is also a pending research issue to ascertain the usefulness of predawn $\mathrm{SC}_{\text {night }}$ in breeding programs under well water conditions, as a trait related to tuber yield.

Acknowledgements This research was conducted under the CGIAR Research Programs (CRP) on Root, Tuber and Bananas (RTB) and Water Land and Ecosystems, and the bilateral projects: - BMZ/GIZ "Improved potato genotypes and water management technologies to enhance water use efficiency, resilience, cost-effectiveness, and productivity of smallholder farms in stress-prone Central Asian environments", PNIA-N": 016-2015-INIA-PNIA/UPMSI/IE "Uso efectivo del agua en el cultivo de papa en zonas áridas: Mejorando el manejo del riego mediante el monitoreo del estatus hídrico para enfrentar al Cambio Climático". Authors thank Libby Rens, Nikolai Alarcón and Jesús Zamalloa for their assistance in the trial management and physiological measurements. Authors are also indebted to MSc. Felipe de Mendiburu for his advice and support in the statistical analysis and Dr. Victor Mares who helped editing and correcting of the final version of this communication.

Open Access This article is distributed under the terms of the Creative Commons Attribution 4.0 International License (http:// creativecommons.org/licenses/by/4.0/), which permits use, duplication, adaptation, distribution and reproduction in any medium or format, as long as you give appropriate credit to the original author(s) and the source, provide a link to the Creative Commons license and indicate if changes were made.

\section{References}

Ahmadi, S.H., M.N. Andersen, F. Plauborg, R.T. Poulsen, C.R. Jensen, A.R. Sepaskhah, and S. Hansen. 2010. Effects of irrigation strategies 
and soils on field grown potatoes: Yield and water productivity. Agricultural Water Management 97: 1923-1930.

Blom-Zandstra, M., C.S. Pot, F.M. Maas, and A.H.C.M. Schapendonk. 1995. Effects of different light treatments on the nocturnal transpiration and dynamics of stomatal closure of two rose cultivars. Scientia Horticulturae 61: 251-262.

Caird, M.A., J.H. Richards, and T.C. Hsiao. 2007a. Significant transpiration water loss occurs throughout the night in field-grown tomato. Functional Plant Biology 34: 172-177.

Caird, M.A., J.H. Richards, and L.A. Donovan. 2007b. Nighttime stomatal conductance and transpiration in $\mathrm{C} 3$ and $\mathrm{C} 4$ plants. Plant Physiology 143: 4-10.

Condori, B., R.J. Hijmans, R. Quiroz, and J.F. Ledent. 2010. Quantifying the expression of potato genetic diversity in the high Andes through growth analysis and modeling. Field Crops Research 119: 135-144.

Dodd, A.N., N. Salathia, A. Hall, E. Kevei, R. Toth, F. Nagy, J.M. Hibberd, A.J. Millar, and A.A.R. Webb. 2005. Plant circadian clocks increase photosynthesis, growth, survival, and competitive advantage. Science 309: 630-633.

FAO. 2016. World crop production statistics. http://faostat.fao.org. Accessed 10 Sept 2016.

Marks, C.O., and M.J. Lechowicz. 2007. The ecological and functional correlates of nocturnal transpiration. Tree Physiology 27: 577-584.

Matimati, I., G.A. Verboom, and M.D. Cramer. 2014. Do hydraulic redistribution and nocturnal transpiration facilitate nutrient acquisition in Aspalathus Linearis? Oecologia 175: 1129-1142.

McClung, C.R. 2006. Plant circadian rhythms. Plant Cell 18: 792-803.

Monneveux, P., D.A. Ramírez, and M.T. Pino. 2013. Drought tolerance in potato (S. tuberosum L.): Can we learn from drought tolerance research in cereals? Plant Science 205-206: 76-86.
Monteith, J.L., and M. Unsworth. 2001. Principles of environmental physics. 2nd ed. Oxford: Butterworth-Heinemann.

Ramírez, D.A., W. Yactayo, L.R. Rens, J.L. Rolando, S. Palacios, F. De Mendiburu, V. Mares, C. Barreda, H. Loayza, P. Monneveux, L. Zotarelli, A. Khan, and R. Quiroz. 2016. Defining biological thresholds associated to plant water status for monitoring water restriction effects: Stomatal conductance and photosynthesis recovery as key indicators in potato. Agricultural Water Management 177: 369-378.

Raymundo, R., S. Asseng, D. Cammarano, and R. Quiroz. 2014. Potato, sweet potato, and yam models for climate change: A review. Field Crops Research 166: 173-185.

Resco de Dios, V., J. Roy, J.P. Ferrio, J.G. Alday, D. Landais, A. Milcu, and A. Gessler. 2015. Processes driving nocturnal transpiration and implications for estimating land evapotranspiration. Scientific Reports 5: 10975.

Resco de Dios, V., M.E. Loik, R. Smith, M.J. Aspinwall, and D.T. Tissue. 2016. Genetic variation in circadian regulation of nocturnal stomatal conductance enhances carbon assimilation and growth. Plant Cell. Environment 39: 3-11.

Rolando, J.L., D.A. Ramírez, W. Yactayo, P. Monneveux, and R. Quiroz. 2015. Leaf greenness as a drought tolerance related trait in potato (Solanum tuberosum L.). Environmental and Experimental Botany 110: 27-35.

Schoppach, R., E. Claverie, and W. Sadok. 2014. Genotype-dependent influence of night-time vapour pressure deficit on night-time transpiration and daytime gas exchange in wheat. Functional Plant Biology 41: 963-971.

Tourneux, C., A. Devaux, M.R. Camacho, P. Mamani, and J.F. Ledent. 2003. Effect of water shortage on six potato genotypes in the highlands of Bolivia (II): Water relations, physiological parameters. Agronomie 23: 181-190. 